\title{
PERIPHERAL TOURISM TRAJECTORIES: EVIDENCE FROM THE KING SABATA DALINDYEBO MUNICIPALITY, SOUTH AFRICA
}

\author{
Christian M. ROGERSON * \\ University of Johannesburg, School of Tourism \& Hospitality, \\ College of Business \& Economics, Johannesburg, South Africa, email: crogerson@uj.ac.za
}

\begin{abstract}
Citation: Rogerson C. M., (2019). PERIPHERAL TOURISM TRAJECTORIES: EVIDENCE FROM THE KING SABATA DALINDYEBO MUNICIPALITY, SOUTH AFRICA. GeoJournal of Tourism and Geosites, 26(3), 974-992. https://doi.org/10.30892/gtg.26323-411
\end{abstract}

\begin{abstract}
Peripheral tourism is a major theme for tourism scholars. This article contributes to the expanding international debates and writings surrounding 'tourism in peripheries' and of peripheral tourism development. It applies a longitudinal research approach towards the evolution of tourism in one particular marginal tourism region in the global South. The geographical focus is South Africa where the space economy exhibits a core-periphery structure. The paper traces the trajectory of tourism development which has occurred in one peripheral region of the country. The case study is of King Sabata Dalindyebo Local Municipality in Eastern Cape province. This is an area of particular interest as it incorporates much of the territory that was the former Transkei homeland. The discussion shows that the historical growth of different forms of tourism in this municipality exhibits marked differences between its inland and coastal areas. Importantly, the contemporary tourism economy of this peripheral region shows signs of serious decline despite tourism being acknowledged as one of key drivers for local development.
\end{abstract}

Key words: Peripheral tourism, historical tourism, Transkei Homeland, South Africa

\section{INTRODUCTION}

Questions surrounding 'peripherality' and the development of tourism in 'peripheral regions' continue to attract a vibrant scholarship (Hohl \& Tisdell, 1995; Wanhill, 1997; Brown et al., 2000; Moscardo, 2005; Chaperon \& Bramwell, 2013; Pezzi, 2017a; Pezzi \& Urso, 2017; Salvatore et al., 2018; Pezzi et al., 2019). In theories of regional or spatial development the term 'periphery' has become synonymous with localities that are 'less developed', 'underdeveloped' or 'distressed' as compared to the state of development of more prosperous 'core' regions (Pike et al., 2006, 2015; Rogerson, 2015). Pezzi \& Urso $(2016,2017)$ highlight both the opportunities and constraints of peripherality with policy suggestions for overcoming marginalisation challenges through a search for new paths of resilience in peripheral regions. For tourism scholars the

\footnotetext{
${ }^{*}$ Corresponding author
} 
concept of a 'core-periphery' dichotomy in space economies remains at the centre of discussions about tourism as a potential vehicle for encouraging economic growth and employment opportunities in peripheral regions and for breaking down existing spatial structures (Christaller, 1964; Müller \& Jansson, 2007; Hall, 2013). Much literature about tourism in peripheral regions directly focuses on tourism's role (or potential) for generating economic growth, enterprise development, and livelihood improvements (Keller, 1987; Brouder, 2013). Other key research foci relate to management issues, entrepreneurship and of niche tourism promotion (Moscardo, 2005; Chaperon \& Bramwell, 2013; Dinis \& Krakover, 2016; Pezzi, 2017a, 2017b; Salvatore et al., 2018; Pezzi et al., 2019). This paper contributes to these expanding international debates and writings surrounding 'tourism in peripheries' and of peripheral tourism development. More specifically, it seeks to offer fresh insight into peripheral tourism by adopting a longitudinal approach towards the evolution of tourism in one particular marginal tourism region in the global South. Arguably, the impacts of 'peripheralisation' processes are most clearly visible in remote, isolated or 'excluded' areas of national space economies (Pezzi, 2017a; Lang \& Görmar, 2019).

The geographical setting for this investigation is South Africa which manifests a distorted core-periphery structure with massive, historically structured and deep-seated unevenness in patterns of spatial development (Todes \& Turok, 2018). In South Africa, as in many parts of Europe, tourism is viewed as a vehicle for local and regional development and around this theme there are several relevant existing academic works (Rogerson, 2014a, 2015; Nel \& Rogerson, 2016; Rogerson \& Rogerson, 2019a).

The objective in this paper is to trace the pathway or trajectory of tourism development which has occurred in one peripheral region of the country. The specific regional focus is upon what is now termed the King Sabata Dalindyebo Local Municipality, an area which is of particular interest as it incorporates much of the territory that was the former Transkei Homeland. Three sections of discussion and analysis are presented. First, a background sketch is given of the case study region to demonstrate the characteristics of this peripheral area of South Africa. Second, drawing upon a range of archival source material, a longitudinal approach is taken to track the evolution of tourism beginning in the colonial period and continuing to the period of democratic change in 1994. The third section shifts to investigate the state of the area's contemporary tourism economy and reveals the stagnant character of peripheral tourism.

\section{RESEARCH CONTEXT}

The King Sabata Dalindyebo Local Municipality (KSDM) is part of the O.R. Tambo District Municipality (DM) in Eastern Cape province. It is the largest of the five municipalities that comprise O.R. Tambo DM accounting for a quarter of its geographical area. The KSD municipality comprises a major section of what was the former Transkei Bantustan which was constituted in the apartheid period.

The KSD municipality was formed in 2000 before the local government elections as a result of the merger of the Mqanduli and Mthatha Transitional and Rural Councils. The majority of the population resides in rural settlements; the two largest centres are Mqanduli and Mthatha, which was formerly named Umtata until March 2004 (Ngwira, 2011). The KSD Municipality also incorporates a small section of the Wild Coast as the mandate of the municipality stretches to include the coastal tourist hub of Coffee Bay and the iconic visitor attraction of the Hole in the Wall (Fig 1). The municipality has a total population estimated (2016) as 490 ooo (99.1 percent described as Black African) of which 310 ooo are classed as living in rural traditional settlements (Eastern Cape SocioEconomic Consultative Council, 2017). A gender imbalance exists with 54 percent of the 
population female which is a reflection of the area's history as a cheap labour reservoir for male migrant workers employed elsewhere in South Africa. The main urban centre of Mthatha has a population of about 150000 albeit it caters for the needs of over 1.5 million people who live within a $50 \mathrm{~km}$ radius of the town (Dzinotyiweyi, 2009). Mthatha is one of South Africa's urban centres where a major section of its residents are accommodated in characteristically rural settings (de Witt \& Ndzamela, 2018). In functional terms Mthatha is a regional powerhouse as it serves as an economic and social focus for the functionally lower order settlements, both the small towns and their surrounding rural communities (O.R. Tambo District Municipality, 2017).

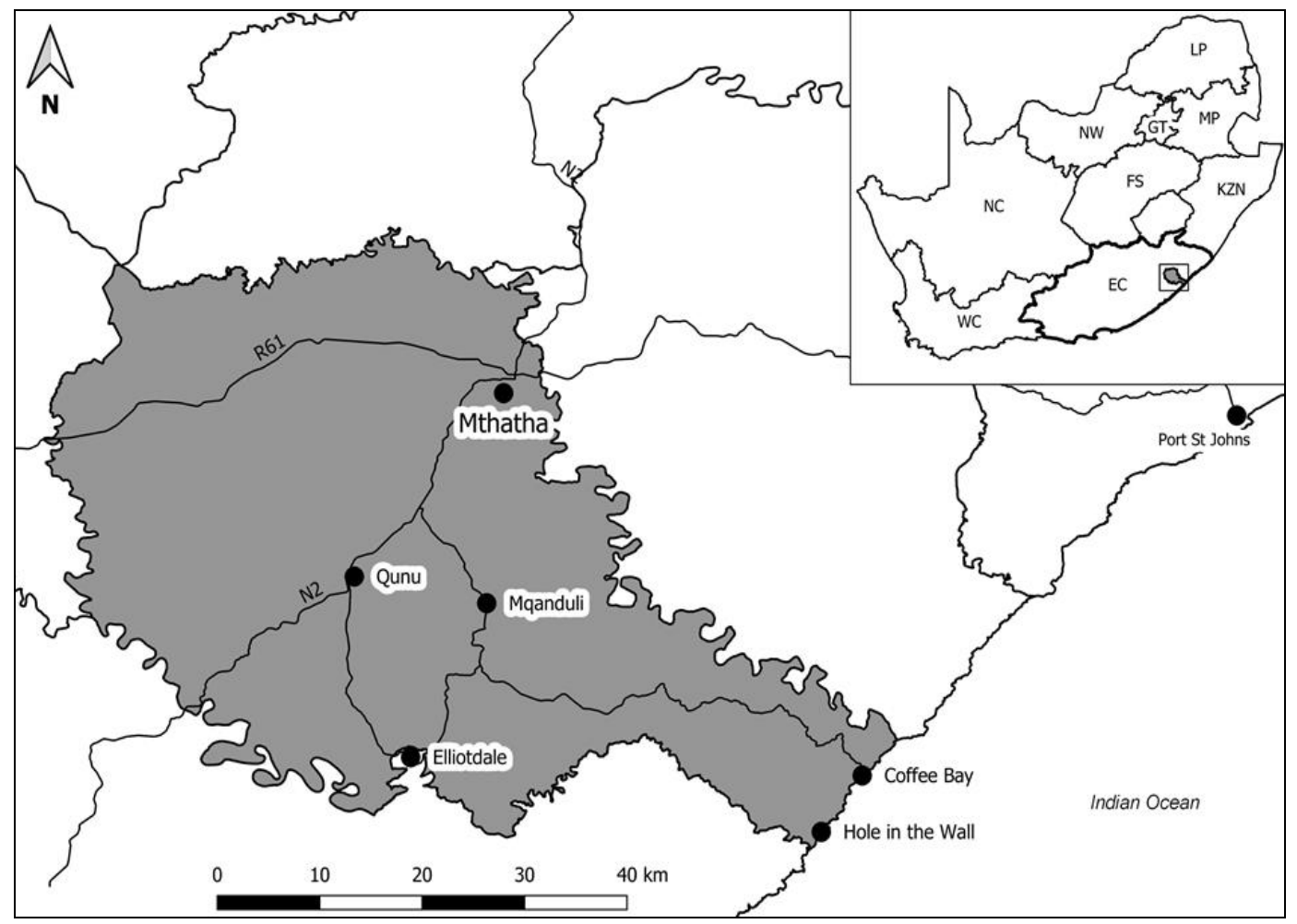

Figure 1. The Location of King Sabata Dalindyebo Municipality, South

In respect of development indicators it is important to appreciate that KSDM would be classed as one of South Africa's most economically distressed and marginalized areas. Widespread poverty exists across the KSDM as well as the O.R. Tambo DM which is one of South Africa's municipalities recording a declining district economy (O.R. Tambo District Municipality, 2017). For Mthatha Harrison (2008) and Tsheleza et al. (2019) state that two-thirds of its citizens live in poverty and as much as 52 percent of them are formally unemployed. Service levels for households and infrastructure are major challenges. De Witt \& Ndzamela (2018: 4) provide a profile for 2016 for the district which reveals only 15.7 percent of local households with indoor water access, 36.7 percent with flush toilet access but with 84.5 percent of households having electricity access, the latter lower than the national South African average. It is argued that the spatial extent of urban sprawl outside the formal urban boundary onto traditional land is one key factor constraining improved service delivery (de Witt \& Ndzamela, 2018). 
Harrison (2008) draws attention to historical factors that explain the municipality's current infrastructural challenges. It is argued the town suffers from a legacy of "historical mismanagement" and that the bulk infrastructure network "was developed for 'the colonial Mthatha of a 100 years ago' and cannot meet the demands of the current population" (Harrison, 2008: 26). Mzamo (2018: 79) records that today Mthatha is overcrowded and has "relapsed into a town of potholes, out-dated sewerage systems, electricity outages and dilapidated buildings". Residents often have to endure lengthy periods without water and with sewerage spills and uncollected garbage a constant sight (Dzinotyiweyi, 2009). Solid waste management is emerging as a major environmental hazard (Tsheleza et al., 2019). Ngwira (2011: 51) adds the impact of HIV/Aids is a further issue "of major concern within the Municipality".

A diagnostic research investigation produced by the Eastern Cape SocioEconomic Consultative Council (2017) pointed to 12.4 percent of the municipal population as infected with HIV. In terms of the local economy this municipality was negatively impacted by 1994 democratic transition and the re-incorporation of Transkei into South Africa (Siyongwana, 2005). Umtata lost its status as a preferred 'growth point' for decentralization of manufacturing in terms of changes in location incentives enacted in 1991. By 1994 it had lost also its former capital city function and later suffered further misfortune in the decision to locate the function of provincial capital of Eastern Cape at Bisho (Siyongwana, 2009). A rebound in the local economy began from 2000 when Mthatha secured its role as administrative centre for the O.R. Tambo DM as well as being the administrative heart for KSDM. The town has only a small manufacturing base although there are announced plans for promoting new agroindustrial enterprises at the Wild Coast special economic zone in Mthatha (Ngcukana, 2018). The ambitious plans for this zone coincide with aspirations of the KSD municipality "to become the first rural metro in the country by 2021/22 and to build a new town in Coffee Bay with a harbour" (Ngcukana, 2018).

The contemporary (formal) economy of KSDM is dominated by government services, finance and trade (de Witt and Ndzamela, 2018). For Mthatha Harrison (2008: 26-27) describes the existence of "a structurally unequal economy" with a small number of large firms dominating the formal economy, a structure that "encourages massive leakages from the town". Beneath the formal economy is an extensive informal economy within which micro-enterprises compete against each other in "the lowest ends of the market owing to their inability to compete against large established firms" (Harrison, 2008: 27). In light of the fragile state of economic development the making of place-based initiatives is urgent for sustainable development of KSDM as a whole and of Mthatha in particular. The capacity for developing such initiatives is, however, constrained. De Witt \& Ndzamela (2018: 7) assessed the municipality's institutional capacity and concluded "it to be seriously lacking". Of particular concern is that in relation to planning for local economic development (LED) the research study by Mbontsi (2008: xi) revealed "the municipality does not understand the concept of LED" and as an outcome "LED is not living up to expectations in the area". This said, in many spheres of its mandate the municipality has good plans in theory albeit "the municipality lacks the people with the competencies to implement" (de Witt \& Ndzamela, 2018: 7). In turn this results in ineffective use of resources and a recurrent crisis in municipal governance (Msi, 2009). It is against this backdrop that attention turns to examine one of the identified potential drivers for growth and poverty alleviation in KSDM, namely the tourism sector (King Sabata Municipality, 2016, 2019). The next section turns to the evolutionary pathway of tourism in this region. 


\section{THE HISTORICAL DEVELOPMENT TRAJECTORY OF TOURISM}

The historical development of tourism in what is now KSDM remains part of the unwritten and so far little researched tourism history of South Africa (Grundlingh, 2005; Rogerson, 2017; Rogerson \& Rogerson, 2018, 2019b; Rogerson, 2019; Sixaba \& Rogerson, 2019). From scattered available information are certain indications of early tourism development in this area. Originally, what is today Mthatha was built as a white settlement in the mid-180os, a buffer between warring African communities over land disputes. Subsequently, the town became a significant logistical hub in the early days of trade and travel in South Africa (de Witt \& Ndzamela, 2018).

For 1920 there is clear evidence that the settlement of Umtata was attracting a flow of travellers in need of commercial accommodation. The Illustrated South African Hotel Guide for 1920 lists the existence of three hotels in Umtata, namely the Imperial, the Grosvenor and Royal (The Union Publishing Agency 1921: 222). By 1935 Umtata was the terminus of the railway line from East London and an important trading centre for the Transkeian territories. A marketing brochure produced in 1935 by the East London publicity association describes the town as the "Administrative Capital of the Transkeian territories" and geographically situated "amidst fine mountain scenery" and enjoying "an equable climate" (East London Publicity Association, 1935: 92). In terms of further publicizing the town for visitors the guide stated as follows: "Umtata is rich in history, closely bound up with that of the troublous early days in the Transkei, and with devoted missionary enterprise" (East London Publicity Association, 1935: 92).

Further, it was pointed out that the town was "romantic in history" and "situated in the heart of a native population of well over a million souls" (East London Publicity Association, 1935: 95). A 1936 national guide describes the town as "capital of Tembuland situated on the banks of the Umtata River near Umtata Falls" (South African Railways and Harbours, 1936: 192). It recorded the three same established hotels - Grosvenor Hotel, Hotel Imperial and Royal Hotel - each of which charged between $10 \mathrm{~s} 6 \mathrm{~d}$ and $12 \mathrm{~s} 6 \mathrm{~d}$ per day for accommodation (South African Railways and Harbours, 1936). At the coast whilst there existed no formal accommodation establishments the beginnings of Coffee Bay as a leisure destination were marked by the appearance of holiday cottages during the 1940s (Ashley \& Ntshona, 2003; Wildman, 2005). For travellers detraining at Umtata, tourism marketing material produced in 1937 for South African railways characterized it as "the gateway to a region which is one of the most beautiful in Southern Africa" (Carlyle-Gall, 1937: 75). In detail its attractions were described as follows: "In this entrancing land live, in quaint primitiveness, over 1,000,000 natives. The impressions which the traveler of this modern age gains while touring so unique a territory must surely come to him as a revelation. The South African, accustomed as he is to seeing the native as a labourer, in European clothes of sorts, endeavouring to adjust himself to a complex - and what is to him a totally foreign - environment, will observe, almost at every turn, some new aspect of untrammelled and picturesque Bantu life which will increase his understanding of this interesting human type. To the overseas visitor, inured to the dayand-night clamour of incessant traffic and to the seething population of a crowded capital of the Northern Hemisphere, a journey in this strange and primeval land is still more impressive. The markedly progressive towns and villages, collectively of only some 17, ooo Europeans, are in striking contrast to their surroundings, and once he departs from these centres of the white race, the sightseer leaves civilization behind and finds himself in a region over which reigns the age-less peace of Africa" (Carlyle-Gall, 1937: 75).

The appeal of the Transkei was viewed as particularly strong for international tourists visiting South Africa. Just prior to the outbreak of the Second World War it was observed: "It is the unique privilege of the visitor to South Africa to be able, as it were, 
to step from the pulsating twentieth-century scene into a vastly different world - the ancestral domain of the native. And in the Transkeian Territories human society in its very beginning is to be seen in the weirdly-romantic native reserves" (Carlyle-Gall, 1937: 77). Further later publicity material produced by South African Railways Tourist Office (1949) and targeted mainly at potential international travellers to South Africa continued to emphasise the "primitive" attractions and customs of the people of the "Native Territories". Indeed, in 1949 the Transkei was described as a "singularly rich field for the searcher after the primitive" (South African Railways Tourist Office 1949: unnumbered page 2). The following description was offered to lure the curious international tourist: "Here the Native goes about his daily round in much the same manner as he did before the coming of the white man. Tribal customs are observed with all their colourful solemnity; periodical dances are staged with vigorous enthusiasm; and even in respect of simple domestic duties the ways of the Native are full of quaintness and interest to folk accustomed from infancy to European ideas" (South African Railways Tourist Office 1949: unnumbered page 2).

During the apartheid period national government began to express growing interest in the potential for encouraging tourism development in the so-termed Bantustans or Homelands. In particular, mounting policy concern occurred in the 1960 s. It was inseparable from the imperative of providing some façade of economic legitimacy to national government planning of these spaces as 'separate' from and potentially 'independent' of the space of so-termed 'White' South Africa. In 1963 Transkei assumed the status of a 'self-governing' territory with the powers of the Transkeian General Council (or Bunga), endowed with a new Constitution, expanded as it became the Transkei Legislative Assembly. From the limited available source material on accommodation there are signals of some growth in the tourism economy of what would become KSDM. The 1965 national guide lists four hotels in Umtata, viz., the Grosvenor (46 rooms 5 with private bath), the Imperial (40 rooms 8 with private bath), the Royal (53 rooms 2 with private bath) and - the largest - the newly established Savoy (92 rooms and 44 with private bath) (Hotel Guide Association, 1965). In addition, the 1965 Hotel Guide lists the 10 room Union Hotel in Mqanduli; no hotel establishments were given for the coastal area (Hotel Guide Association, 1965). By 1972, however, the national Hotel Guide records the Union at Mqanduli as well as five hotels in Umtata, with the most recent addition being the unregistered 40 room Transkei Hotel (Hotel Board South Africa, 1972). Further, the same guide lists two unregistered hotel establishments now operating at Coffee Bay, those being the 42 room Lagoon Hotel and the 40 room Ocean View Hotel. Wildman (2005: 88) argues that during the 1960s Coffee Bay began to attract "a lot of domestic tourists". During the early 1970s Coffee Bay even could be styled as "a flourishing holiday village" that was an increasing popular focus for the growing market of (white) domestic tourism under apartheid (Wildman, 2005: 96). Indeed, as part of South Africa's pleasure periphery, Wildman (2005: 96) observes that "Coffee Bay had enjoyed a reputation of being a 'trouble free', 'normal' and 'uncomplicated' destination - a place where white South Africans really could be free".

A major turning point in the trajectory of KSDM as a tourism area came with Transkei independence. Notwithstanding widespread opposition expressed towards the implementation of separate development and that independence on 26 October 1976 was seen as "illegitimate" and "white-imposed from Pretoria" (Streek \& Wicksteed, 1981: 7) Transkei became the first of four of South Africa's ten Bantustans to accede to 'independence'. Much window-dressing was necessary however, to make Umtata - along with other independence capitals such as Mmabatho, Thohoyoandou and Bisho - an international showcase for Bantustan development (Siyongwana, 2009: 293). During the 
apartheid period tourism developers and Bantustan governments were facilitated to take advantage of the status of 'independence' as a means to circumvent South African government restrictions towards what was deemed as such 'morally dubious' activities as gambling, inter-racial relations and pornography. The Transkei, as with other subsequent 'independent' Bantustans, "provided the ideal location for white South Africans to indulge themselves" (Wildman, 2005: 86). The first casino/resort complex to be launched in Transkei by Holiday Inn opened its doors for pleasure seekers at Mazamba which adjoins the Natal South Coast in December 1981. It was targeted especially at white domestic tourists as well as the day visitor market from Durban (Crush \& Wellings, 1983).

At this time the Transkei was a region newly attracting the investment interest of South Africa's major hotel enterprises, several of which examined opportunities for casino development mainly in the territory's coastal areas. That said, it was reported that during 1980 the Southern Sun group were exploring potential hotel sites across Transkei including an investigation of the possibilities of developing "a complex overlooking the sprawling Mtata Dam, $6 \mathrm{~km}$ from Umtata” (Rand Daily Mail, 24 July 1980). New investment began to flow into the hotel economy of Umtata as shown by the opening of the 117 bed Holiday Inn which became the town's largest hotel. The 1981 tourism guide identifies, however, few leisure activities for visitors to Umtata. The only exceptions were of "excellent waters for trout fishing" in the local area (Republic of Transkei, 1981: 34) as well as sport fishing for eels along the Umtata river. Nevertheless, the possibilities for enjoying a leisure experience in Umtata were marketed in promotional material issued by the town's hotels. The Transkei Hotel, for example, proclaimed it was where "international travelers meet" and that "For those who feel romantic we have the Rooftop Terrace. What better way to spend a quiet evening relaxing and watching the sun sinking slowly over the lush greenery that is Transkei" (Republic of Transkei, 1981: 41).

Notwithstanding its limited attractions for the leisure traveler new possibilities emerged with independence for Umtata to expand its economy of business tourism. With accession to 'independence' Umtata acquired the status as well as some of the associated trappings of a 'national' capital city (Siyongwana, 2009). Opportunities opened up here for the further flow of business tourists including of international business tourists' through the steady flow of diplomats and government officials from Pretoria. Arguably, following independence, business tourism must have expanded in significance associated with the growth of government administrative functions (Siyongwana, 2009) and thus a boost overall to Umtata's tourism local economy. Umtata was the road and air transportation focus for Transkei as well as the hub of Transkei Airways which operated 20 flights a week between Johannesburg and Umtata.

By the early 1980 s further promotion was undertaken of Transkei's potential as a leisure tourism destination. Ashley \& Ntshona (2003: 8) observed that "tourism came to be seen as a source of income" and planning for the coastal areas was based on the identification of several key nodes, of which Coffee Bay was one, and leaving the rest of the coastline in its natural state. In 1981 the Transkei Department of Planning and Commerce issued an official visitor guidebook which stated as follows: "Transkei is a country of considerable beauty ranging from indigenous forests in its inland mountain areas to a unique coastline which is unequalled for its unspoilt natural beauty. The policy of my Department is to preserve the beauty of the coastline and at the same time to encourage tourist development in selected areas" (Republic of Transkei, 1981: 2). In what is now KSD the major leisure tourism developments occurred not in Umtata but instead at the coastal areas around Coffee Bay. The 1981 guide listed still only two hotels - the Ocean View and the Lagoon Hotel - at what was described now as "the picturesque resort" of Coffee Bay (Republic of Transkei, 1981: 44). In its advertising the 
Ocean View Hotel provides details of its amenities as well as core attractions for tourists that include "private beach, excellent surfing, surf and rock fishing" as well as tennis court, full sized snooker table and evening relaxation at the hotel's bar.

Using oral testimonies and archival research Wildman's (2005: 87) rich research at Coffee Bay documents that whilst 'independence' for Transkei "may have created new forms of tourism opportunities for the black government, it at the same time upset the region's traditional tourist base". Coastal tourism proprietors reported that occupancy rates dropped dramatically following 'independence' as the core base of regular white domestic tourists was nervous if not 'scared' of holidaying in an area with a black government. The forcing out of white hotel owners after the black government came to power reduced management capacity and standards as by 1982 the two hotels had been taken over by the Transkei Development Corporation with limited managerial capacities (Wildman, 2005: 89). Nevertheless, the main reason for the collapse in Coffee Bay tourism was the decline of essential services including of a daily bus service that formerly ferried basic supplies to Coffee Bay from Umtata. The situation at Coffee Bay worsened throughout the 1980 s especially so following the first military coup of September 1987. A second attempted countercoup was accompanied by attacks both on the hotels and tourists. The consequences of these events for the two Coffee Bay hotels were disastrous. As chronicled by Wildman (2005: 95) "frightened South African holidaymakers cancelled bookings and began staying away in droves”. Inevitably, with the rapid hollowing out of Coffee Bay's tourism economy both hotels were forced to close operations: "first the Lagoon, which closed not long after the coups, and then the Ocean View in 1989" (Wildman, 2005: 95).

Put simply, Transkei independence was the beginning of the end for the traditional domestic holiday market that had long supported tourism growth at Coffee Bay. The coups immediately and irreparably damaged the region's image as the perfect pleasure periphery as "white South African tourists looked elsewhere for a new idealized vacationscape to inhabit" (Wildman, 2005: 95). Overall, the 'innocence' of Coffee Bay was destroyed and immediately issues of safety became paramount as opposed to traditional established views of Coffee Bay as a 'value for money' domestic tourism destination. By the late 1980 s Coffee Bay was described as a virtual ghost town. Even into the 1990 s amidst signs of political change a sense of danger continued to define tourism in the local area and for Transkei as a whole (Wildman, 2005). Only with the 1994 democratic transition and reintegration of Transkei into South Africa there began to emerge a radical change in the environment for tourism development in what would later become KSDM.

It can be observed that just as independence in 1976 set the conditions for different trajectories for tourism development in Umtata as opposed to Coffee Bay, so also democratic transition introduced fresh possibilities and divergent tourism development pathways for the two centres. In the case of Umtata political change and Transkei's remerger into South Africa meant loss of national capital status and being relegated to the reduced role of "a medium regional urban centre" (Siyongwana, 2005: 201). Transkei was subsumed into the new Eastern Cape Province despite lobbying attempts for Umtata to be capital of "a tenth province consisting of the Transkei, the border (part of Ciskei and East London environments) and East Griqualand" (Siyongwana, 2009: 294). The loss of national capital status was compensated for only partially by Umtata becoming the core administrative centre for the King Sabata Local Municipality and the O.R. Tambo District Municipality. As a result of these regional administrative functions Umtata retained some of its potential attractiveness for business tourism, albeit now almost exclusively for regional domestic visitors as opposed to the former flow of 'international' business.

The altered prospects for business tourism associated with democratic transition were paralleled by different prospects for leisure tourism in the coastal centre of Coffee 
Bay. Although some observers likened the Transkei in 1995 to a 'war zone' which was besieged by 'lawlessness' in terms of violence and escalating crime, reintegration into South Africa at least brought a degree of political stabilization and the end of the era of military coups and countercoups. The Wild Coast Spatial Development Initiative, part of a series of such geographically targeted planning initiatives launched by South Africa's Department of Trade and Industry in the late 1990s, sought to attract new private investment into several coastal zones of the former Transkei, including Coffee Bay (Kepe et al., 2001; Ashley \& Ntshona, 2003). Post-1994 witnessed a return of tourism investors into Coffee Bay. As Wildman (2005: 104) reflects whilst "the question of the former homeland's safety kept white South African family vacationers away, it simultaneously began to attract a more adventurous type of tourist - the independent backpacker". Two entrepreneurial local white residents of Coffee Bay observed this change and in 1996 opened the first backpacker hostels. Prior to 1994 backpacker tourism hardly existed in South Africa as the country was shunned by international youth travelers because of the stain of apartheid planning (Rogerson, 2011). Since the democratic transition, however, South Africa has emerged as an increasingly popular destination for international youth travel, especially of backpackers as well as volunteer tourists (Visser, 2004; Rogerson, 2011).

As a result of its attractive natural scenery and beach Coffee Bay and its surrounds became one of the emerging 'hotspots' for international backpackers visiting South Africa (Rogerson, 2011). In addition, high levels of visitation were recorded by communities of international volunteers (Heer, 2007). Essentially, Coffee Bay was re-visioned and repackaged as an "undiscovered, uninhabited paradise to attract a new generation of voyagers to its shores" (Wildman, 2005: 114). In addition, with safety reassured Coffee Bay also was re-discovered by the mainly white South African holidaymaker as an attractive leisure destination as well as becoming a popular destination for day visitors from local urban centres (Mthatha, Elliotdale) in proximity. Argues Wildman (2005: 114) "by the beginning of the new millennium, Coffee Bay, having been rediscovered and reinvented, regained its popularity as the ideal tourist dreamscape".

\section{THE CONTEMPORARY TOURISM ECONOMY}

Two sub-sections of discussion are provided concerning the contemporary tourism economy of the municipality. First, an analysis is undertaken of key tourism trends and patterns of tourist trips. Second, the nature of the changing accommodation sector in the municipality is reviewed.

\section{Tourism Trends}

Prior to 2000 there is no data available on tourist numbers to the area which could provide a breakdown of the tourism economy in terms of the relative importance of domestic as opposed to international travellers, the different purpose of travel by tourists or of the relative importance of tourism for the local economy of King Sabata Dalindyebo Municipality. From 2001 however a profile of the tourism economy can be gleaned from the unpublished data base of the private sector organization IHS Global Insight. As official data in South Africa is not collected to enable a mapping out of the economic contribution of tourism at a locality scale use is made of this unpublished data base obtainable from IHS Global Insight. The IHS Global Insight data is widely used in local economic development planning in South Africa and observed as applied in the case of KSD municipality in its Integrated Development Planning (King Sabata Municipality, 2016, 2019). IHS Global Insight collates data regularly from a wide range of sources (official and non-government) with the primary data reworked for consistency across variables and by applying national and sub-national verification tests to ensure that the model is consistent for measuring business activity. The data set is 
analysed at the scale of the local municipality as a whole and is supplemented by and triangulated with the results of other investigations of tourism in the municipality.

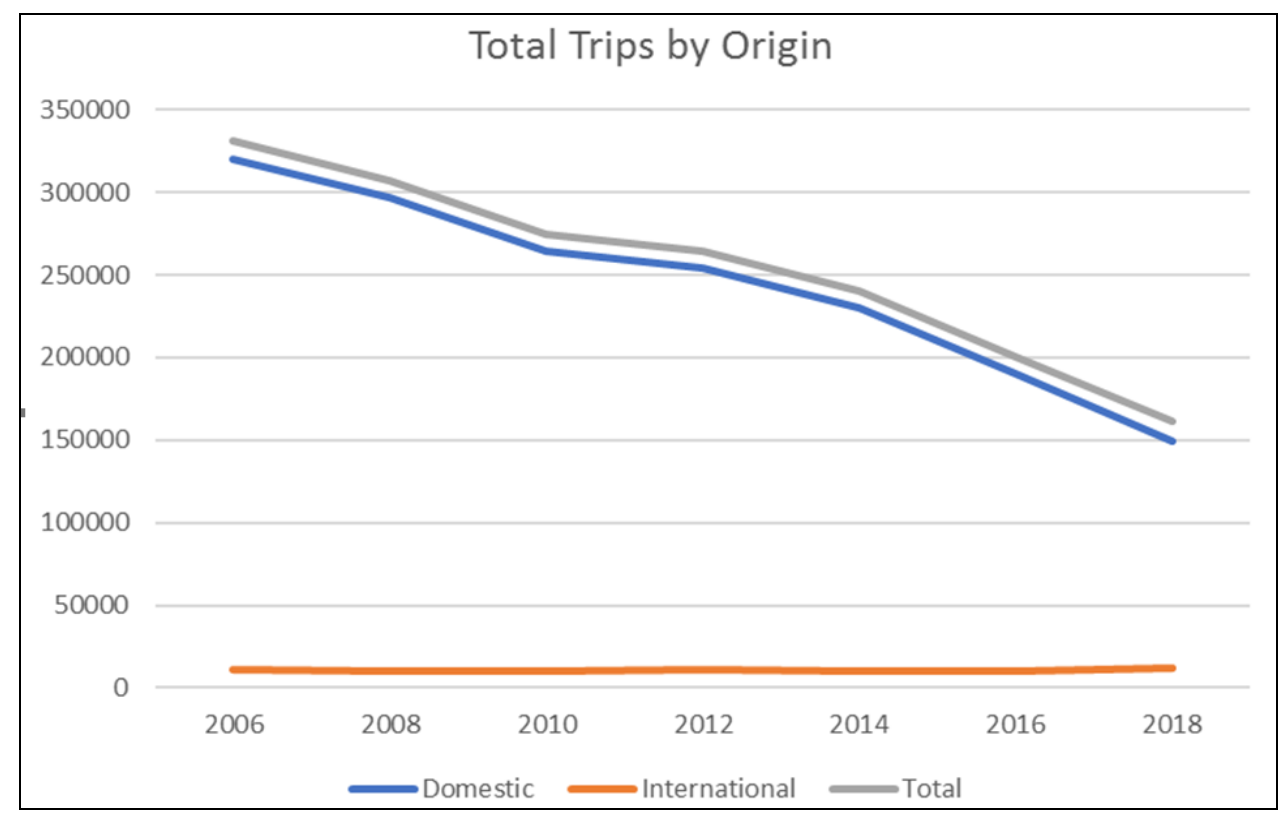

Figure 2. King Sabata Dalindyebo Municipality: Total Trips by Origin 2006-2018 (Source: Based on IHS Global Insight data)

The key finding that emerges from the analysis of the IHS Global Insight data is that of the increasing weakness of the tourism industry across the KSD municipality. During a period marked by a considerable expansion as a whole of the tourism economy for South Africa the performance of the local tourism sector of KSDM has been unpromising. Between 2001 and 2006 in terms of total tourist trips to KSDM there did occur an upturn and expansion from a total of 250000 trips in 2001 to 332000 by 2006. This pattern of growth, however, halted by 2006. Since that time there has been an accelerating decline in total tourist trips to the district.

This downturn is particularly marked since the 2008 financial crisis and the subsequent impact of recession and stagnation of South Africa's national economy. The trajectory of decline was little impacted by South Africa's hosting of the 2010 FIFA World Cup which seemingly had minimal impact for this area. By 2018 the number of tourist trips into KSD had fallen further to reach a total of $152 \mathrm{ooo}$, the lowest recorded number since data has been available for the municipality.

Figure 2 unpacks also the trip data for domestic as opposed to international travelers. It shows that the major decline in the KSDM tourism trip data is the consequence of the massive downturn in domestic tourism since 2006 and especially since 2010. From a total of 318 ooo domestic trips as recorded for 2006 by 2012 the number had fallen to 243 000; by 2018 it was as low as 149000 trips. It is evident that this downturn is a reflection of the broader national pattern of decline in domestic tourism travel in South Africa especially since 2010. For the KSD municipality this demise in domestic visits means that the relative share of domestic tourist trips is reduced somewhat in the overall total share of trips from 96 percent as of 2006 to 93 percent by 2018. Of note also is that the numbers of international tourist visits is 
relatively stable throughout this period. But, in one promising signal for the local economy the number of international trips exhibits a marginal upturn from 2016. By 2018 as a result of the falling numbers of domestic travellers as well as marginal growth in international tourism the share of international trips rises to 7 percent of KSD tourism.

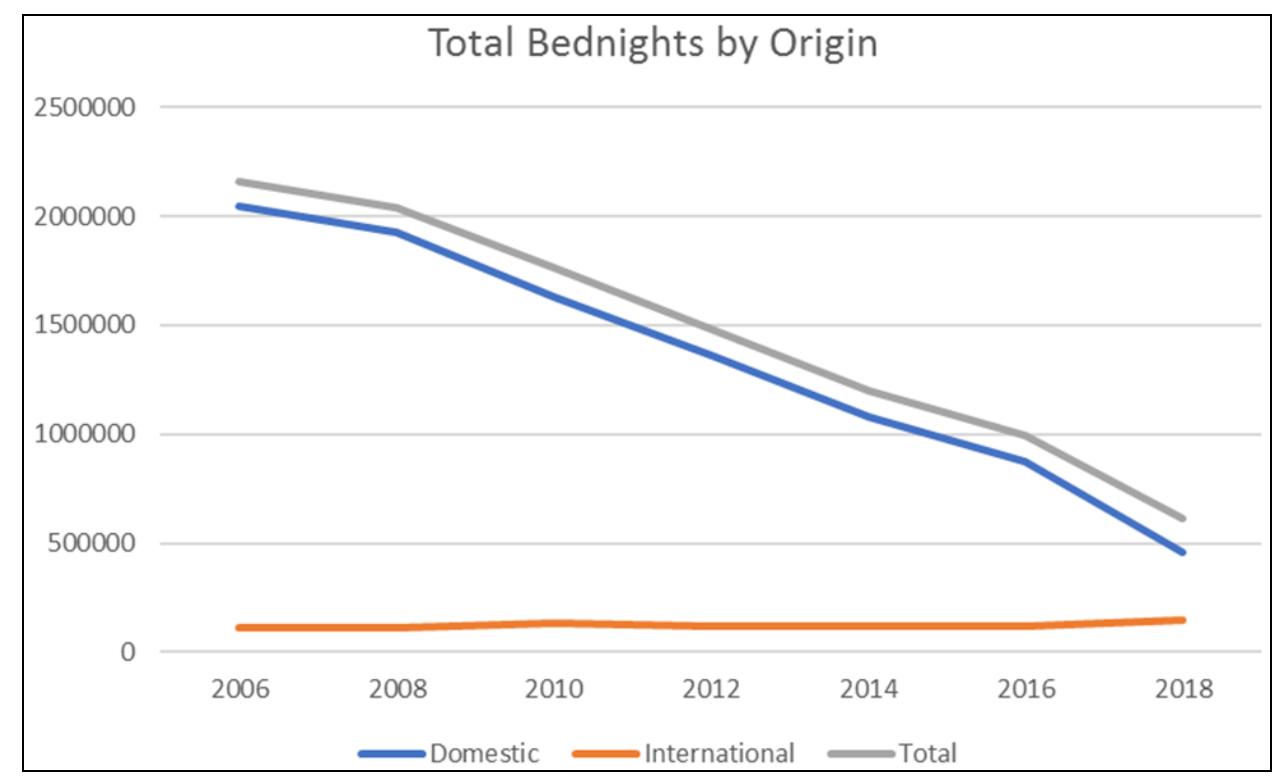

Figure 3. King Sabata Dalindyebo Municipality: Total Bednights by Origin 2006-2018 (Source: Based on IHS Global Insight data)

In parallel with the decline in total trips there has occurred a fall in the total recorded number of bednights, a figure that incorporates both paid bednights in commercial accommodation as well as (mostly) unpaid bednights in non-commercial accommodation which are represented by overnight stays at the homes of friends and relatives (Rogerson, 2018). The information for recorded bednights for KSD once again discloses a tourism economy that is experiencing distress if not absolute decline (Fig. 3). Similar trends to those relating to trip data are in evidence in terms of analyzing bednight data. Overall, there is observed a marked downturn in domestic bednights (a significant proportion of which would be taking place in non-commercial accommodation) albeit on a more positive tone a marginal increase is recorded once again for international bednights with a small upturn in visits between 2016 and 2018. Arguably, given that the majority of these international trips are associated with commercial as opposed to non-commercial forms of accommodation this marginal increase in international bednights is welcomed particularly at Coffee Bay and surrounds which is the core spatial focus for international tourists. Although the observed decline in domestic bednights would impact commercial tourism establishments across the KSDM the most affected area would be Mthatha, the core area for domestic tourists.

Figure 4 shows that in terms of purpose of visit the tourism economy of KSDM is massively dominated by the sector of visiting friends and relatives (VFR) travel. This finding is accounted for in terms of the historical emergence of this area as a cheap labour reservoir for 'White' South Africa and the extensive growth of an economy of circulatory migrants as well as the corresponding splitting of households which would have both an urban and rural 'home' (Rogerson, 2014b). The continued high levels of local 
unemployment in the KSD have reinforced this historical arrangement which has remained little altered since democratic transition and the dropping of influx control legislation. The maintenance of split households has the consequence of spurring significant flows of VFR travellers at certain times of year (especially the Christmas/New Year period) for family visits and ceremonies. VFR travel accounts as a whole for nearly 80 percent of trips to KSD with the overwhelming majority of these being domestic trips and occurring in unpaid accommodation (Kyle Business Projects, 2010). It is observed that the VFR travel economy to KSD has been significantly impacted, however, by the downturn and stagnation in South Africa's national economy. Figure 4 shows a remarkable downturn in VFR travel numbers across the period 2006-2018.

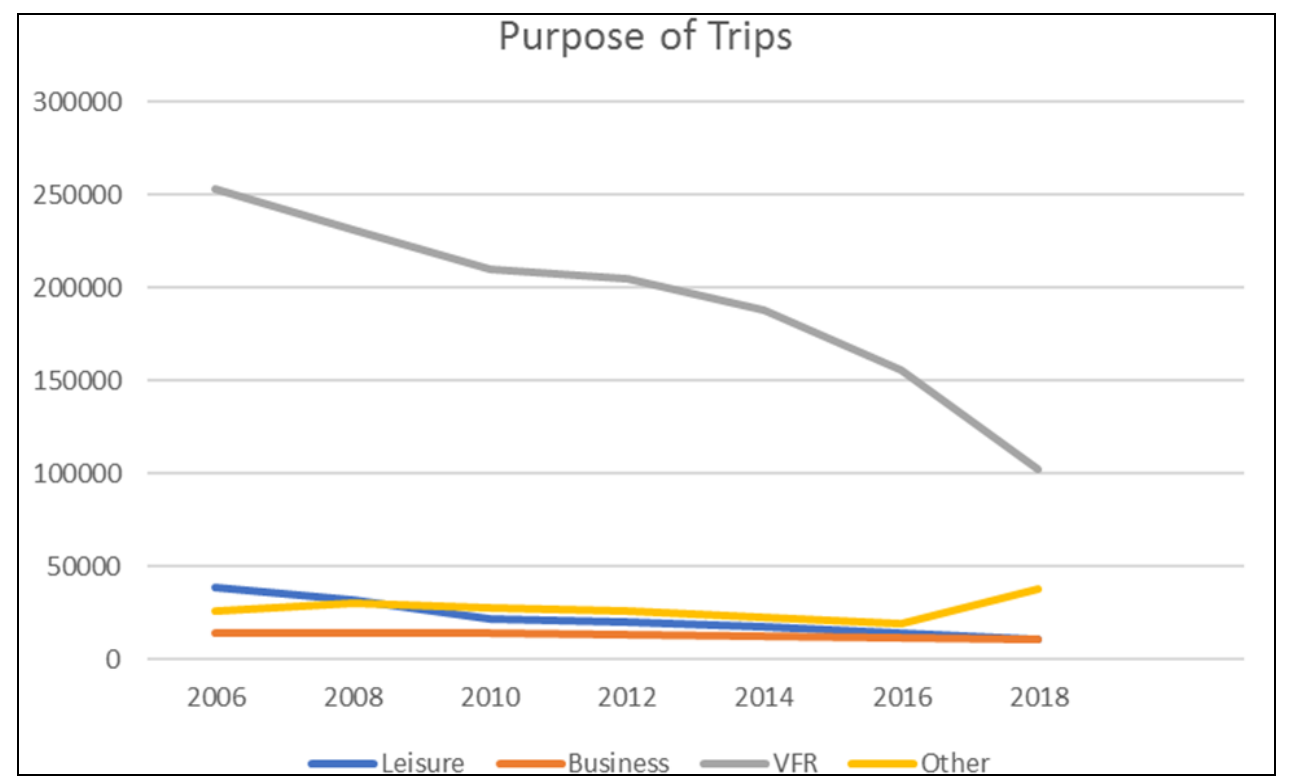

Figure 4. King Sabata Dalindyebo Municipality: Purpose of Travel 2006(Source: Based on IHS Global Insight data)

In terms of leisure travel there is recorded a fall from 50600 leisure visits in 2001 to 39000 by 2006. Across the period 2006-2018 leisure travel has continued to fall such that by 2018 it approximated only 11000 trips or 5 percent of total trips. The decline in leisure trips to KSD must be read against the opening of major new heritage tourism products in Mthatha and surrounds. The most important is the Nelson Mandela Museum which is conceptualized as comprising three interrelated components namely the Bhunga Building (the management and administrative centre), which is at Mthatha; the Nelson Mandela Youth and Heritage Centre (a community museum) at Qunu; and, the open air museum with the Mandela homestead situated at Mvezo, Mandela's birthplace (Mgxwekwa et al., 2019a, 2019b). The museum's so-termed Footprints Trail “extends from its physical facilities, the schools and churches once attended by Nelson Mandela, through the playground (sliding stone of Qunu) of his childhood and the villages that nurtured him to the towns and cities beyond" (Mgxwekwa et al., 2019a: 85).

Leisure travel is of relatively much greater significance for Coffee Bay with its beach attractions, surfing, kayaking and other forms of adventure tourism as well as spectacular natural scenery in its surrounds. Visitor surveys at Coffee Bay highlight that the majority of the destination's visitors are attracted by its relaxed atmosphere, its 
beach and the natural wonder of Hole in the Wall (Sitinga \& Ogra, 2014: 483). The trend for business travel in KSDM is steady; by 2018 it is on a par with leisure travel for numbers of trips. This said business travellers are a critical anchor for accommodation establishments particularly in Mthatha where according to one estimate business tourists represent 81.7 percent of paid commercial accommodation (Kyle Business Projects, 2010). A minor upturn is indicated for recent growth in travel for 'other' purposes which includes for religion, health or sports. Indeed, since 2009 'other' travel has constituted the second most significant purpose of travel for the KSDM.

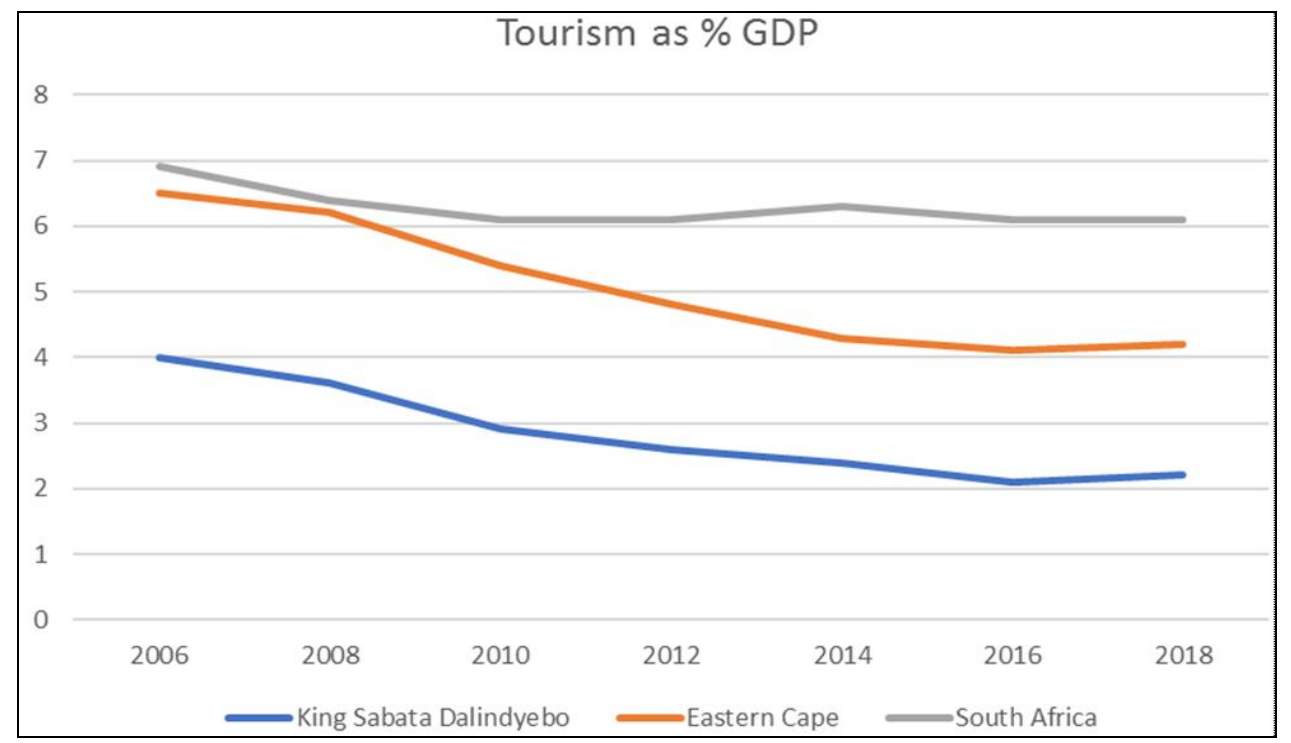

Figure 5. King Sabata Dalindyebo Municipality: Tourism Contribution to Local GDP 2006-2018 (Source: Based on IHS Global Insight data)

The net impact of these downturns in the KSD tourism economy is that in terms of the municipal economy and for local economic development impacts tourism emerges as a sector of only minor significance. Fig. 5 reveals that tourism has been contributing a progressively declining share to local GDP since 2006 when it represented almost $4 \%$ to the local economy. By 2018 this share was diminished to just over $2 \%$ of GDP for KSDM.

\section{Unpacking the Accommodation Sector}

The nature of the accommodation sector of KSD is a reflection of the changing evolution of the tourism economy. Information on the structure of the contemporary accommodation economy of KSD is available from a detailed study which was conducted for the KSD municipality as part of developing a sector plan for responsible tourism (Kyle Business Projects, 2010). This is supplemented by more recent information obtained from a research audit conducted of accommodation establishments across the KSD for 2018.

The 2010 investigation stated that on the supply-side the municipality "has a good selection of accommodation available to the visitor, concentrated mainly in Mthatha and the Coffee Bay/Hole in the Wall areas" (Kyle Business Projects, 2010: 39). The range of different lodging types spans guest houses, bed and breakfast (B\& B) establishments accommodation, self-catering, backpacker hostels and caravan/camping parks. Table 1 provides a summary of the results from the investigation which was conducted in 2010. It shows a tourism economy dominated geographically by the Mthatha cluster, most establishments being accommodation SMMEs mainly B \& Bs. 
Table 1. Supply-Side of Accommodation in KSD Municipality, 2010

(Data source: Adapted after Kyle Business Projects, 2010)

\begin{tabular}{|l|l|}
\hline Accommodation Issue & \multicolumn{1}{c|}{ Key Findings } \\
\hline $\begin{array}{l}\text { Numbers of } \\
\text { Establishments }\end{array}$ & $\begin{array}{l}\text { 104 accommodation establishments with the largest numbers being B } \\
\text { \& Bs (43), guest houses (29), hotels (12) and lodges (11). B \& Bs } \\
\text { constitute 41.3\% of accommodation establishments }\end{array}$ \\
\hline $\begin{array}{l}\text { Numbers of Available } \\
\text { beds }\end{array}$ & $\begin{array}{l}\text { Estimate total 2 894 for the local municipality of which 83 percent } \\
\text { were in Mthatha. Marked differences are observable between Mthatha } \\
\text { and Coffee Bay in terms of accommodation options. In Mthatha most } \\
\text { beds are in B \& Bs (34\%), guest houses (29.8 \%) or hotels (23.9\%) } \\
\text { whereas in Coffee Bay most are found in backpacker hostels (40.3\%), } \\
\text { hotels (31.6\%) or self-catering (13.2\%). }\end{array}$ \\
\hline $\begin{array}{l}\text { Grading of } \\
\text { establishments }\end{array}$ & $\begin{array}{l}\text { Of the total establishments 82\% are not graded (star rated) by South } \\
\text { Africa's tourism grading authority. }\end{array}$ \\
\hline $\begin{array}{l}\text { Grading status of beds } \\
\text { in establishments }\end{array}$ & Estimated 22.2 \% of available beds are in graded establishments \\
\hline Average Bed Occupancy & $\begin{array}{l}32.1 \text { percent across all forms of accommodation. Considerable seasonality } \\
\text { is observable in leisure tourism and occupancies at Coffee Bay. }\end{array}$ \\
\hline
\end{tabular}

The largest share of commercial establishments and available bednights are in ungraded tourism establishments. Lastly, a signal of the weakness of tourism economy and of the struggling nature of the accommodation economy is that overall occupancy rates were calculated at only 32 percent. Further insight into the accommodation structure of the KSD municipality can be derived from a 2019 audit of accommodation establishments conducted across the municipality and from interviews that were undertaken with a small number of suppliers of tourism accommodation at both Mthatha and Coffee Bay. The audit reveals that during a period of the demise of the municipality's tourism economy (2010-2018) there occurred an expansion in the actual number of accommodation establishments. The major findings from the 2018 audit are captured on Table 2. The key findings confirm that the largest number of establishments cluster spatially in Mthatha and surrounds with Coffee Bay (and Hole in the Wall) the second most significant node for the supply of tourism accommodation.

Table 2. Supply-Side of Accommodation in KSD Municipality, 2018

\begin{tabular}{|l|l|}
\hline Accommodation Issue & \multicolumn{1}{|c|}{ Key Finding } \\
\hline $\begin{array}{l}\text { Number of } \\
\text { Establishments }\end{array}$ & $\begin{array}{l}\text { 172 in total. The largest number are described as guest houses (68), } \\
\text { followed by Bed and Breakfasts (61), lodges (16), hotels (13), self- } \\
\text { catering (9), backpacker hostels (4) and camping/caravan park (1). }\end{array}$ \\
\hline $\begin{array}{l}\text { Grading of } \\
\text { establishments }\end{array}$ & $\begin{array}{l}50 \text { of the 172 establishments indicate a quality status ie. 29 percent of } \\
\text { establishments are graded }\end{array}$ \\
\hline Geography & $\begin{array}{l}\text { 153 establishments in Mthatha or surrounds and 19 in Coffee Bay or } \\
\text { Hole In the Wall. Differences in accommodation mix between the two } \\
\text { clusters with Coffee Bay only small hotels, backpackers and camping. } \\
\text { Mthatha with major clusters of guest houses and bed and breakfasts as } \\
\text { well as of a total of 9 hotels. }\end{array}$ \\
\hline Racial Ownership & $\begin{array}{l}\text { On basis of existing evidence at least half of all accommodation } \\
\text { establishments in Mthatha are black-owned including leading hotels, } \\
\text { most B \& Bs, several guest houses/lodges and the local backpacker } \\
\text { hostel. In the Coffee Bay cluster the share of black owned } \\
\text { establishments is much more limited. }\end{array}$ \\
\hline $\begin{array}{l}\text { Informal Commercial } \\
\text { Accommodation }\end{array}$ & $\begin{array}{l}\text { Observed growth of a number of black-owned homestays especially in } \\
\text { Qunu and around Coffee Bay }\end{array}$ \\
\hline
\end{tabular}


In terms of forms of accommodation it is evident once more that the largest number of establishments are small-scale B \& Bs or guest houses but that the group of hotels are significant also for number of beds. Geographical variations exist with the Mthatha lodging economy in terms of establishment numbers which are dominated by B \& Bs and guest houses whereas backpacker accommodation or hotels are the primary forms of available accommodation in the Coffee Bay/Hole in the Wall area. It is noted that new forms of lodging have made their appearance in the KSD municipality; recent additions include the growth of informal homestays (mainly in Coffee Bay and Qunu) and of temporary 'pop-up' luxury 'safari tent' camping in the Coffee Bay environs.

Finally, the 2018 audit was the first of its kind which attempted to identify the racial ownership of accommodation establishments. The results disclose that a significant share of ownership is by Black South Africans, a finding which makes the KSD municipality highly distinctive in terms of other research findings reported for other South African small towns where only minimal ownership of accommodation establishments occurs in the hands of black South African entrepreneurs (see Rogerson \& Rogerson, 2019a). At Mthatha the mass of commercial B \& Bs are black-owned, all the homestays are black-owned family establishments, several guest houses are black-owned as is the local backpacker hostel, and black ownership extends even to at least two of the leading hotels in Mthatha. By contrast, at Coffee Bay the major hotels and backpacker hostels remain mainly white-owned albeit the survey did disclose the appearance of a number of black-owned accommodation establishments (including of homestays) in the coastal area. Overall, it is concluded that in terms of actual establishments - including the burst of new informal homestays - that the majority of formal as well as informal accommodation establishments in the KSD are black-owned.

Table 3. Characteristics of Accommodation Enterprises in the Local Municipality

\begin{tabular}{|l|l|}
\hline Accommodation Issue & \multicolumn{1}{c|}{ Key Finding } \\
\hline Visitor Profile & $\begin{array}{l}\text { Marked differences between Mthatha and Coffee Bay. At Mthatha 80 } \\
\text { percent domestic and 70 percent of visitors on business. At Coffee Bay } \\
\text { 90 percent international and 95 percent leisure. }\end{array}$ \\
\hline Length of Business Operation & 80 percent in business for >5 years and 40 percent for more than 10 years \\
\hline Grading of Establishments & 70 percent graded, mostly 3 star operations \\
\hline Capital for Business start-up & 90 percent from own funds or friends/family \\
\hline $\begin{array}{l}\text { Reason for Business } \\
\text { start- up }\end{array}$ & $\begin{array}{l}\text { Most respondents highlighted the desire for 'economic freedom', 'need for } \\
\text { employment' or 'need for income' as driver for business development. }\end{array}$ \\
\hline $\begin{array}{l}\text { Participation in } \\
\text { Tourism Decision- } \\
\text { Making }\end{array}$ & $\begin{array}{l}\text { Majority of entrepreneurs (60 percent) were uninformed about } \\
\text { policies that impact tourism development in the municipality. In } \\
\text { addition, 8o percent of respondents expressed the view that they were } \\
\text { not involved in decision-making processes that impact tourism } \\
\text { development in the municipality }\end{array}$ \\
\hline
\end{tabular}

Table 3 provides a summary of the key findings that emerge from the small sample survey that was conducted with tourism entrepreneurs in Mthatha and Coffee Bay about the operational characteristics of accommodation establishments. The results from respondent interviews confirm that marked geographical differences exist in the market for accommodation providers in the Mthatha cluster as opposed to the coastal cluster of enterprises. In Mthatha the core market is for domestic business travellers whereas at Coffee Bay it is largely for international and almost wholly leisure-oriented tourists with a substantial component of backpackers. The nature of the important business tourist market in Mthatha was revealed further in the study to be dominated by visitors linked to the town's administrative function as headquarters of the O.R. 
Tambo District Municipality. Although some respondents observed a small number of private sector business tourists - mainly visits by doctors and lawyers - the vast majority of Mthatha business tourists are related to functions of government.

These include visits either by police officials, nurses or teachers who are attending training courses, meetings and strategic workshops in the town or by local government officials from outside Mthatha to attend meetings at the district municipality offices. Other typical government business tourists would include local tourism officials coming to Mthatha for meetings as well as school inspectors to use the town as a base to conduct their regular inspections of rural schools in the area.

In respect of their business operations as accommodation suppliers the survey highlighted the fact that many are long-established operations and with some in business for 10 years or more. In terms of reasons for business start-up the most common responses concerned the desire for economic freedom and need for employment or source of income which reflect the poor economic circumstances and high levels of unemployment in the KSD municipality. Overall it is evident that entrepreneurial start-up was driven by motivations for financial independence and by the lack of jobs. One respondent indicated that the reason linked to issues of household survival: "It was because I was not in employment at the time and I was the breadwinner in the family". In addition, some respondents cited other motivations for their reason for starting an accommodation enterprise in the municipality: "Leave a mark for future generations" or "I wanted to establish a tourism business within a rural area to prove that rural women can do it". In one case the motive was rooted in racial issues: "It was because of the racial divide - blacks are not usually well received at the white guest houses - so I saw an opportunity to make black guests feel at home". Whatever the rationale for business formation, as is typical for most SMMEs in South Africa, the source of capital start-up was either through own savings or financial support from family rather than institutional support. As the sample was dominated by established enterprises it is noteworthy that the majority were registered enterprises and graded in terms of the quality standards of national grading authorities. Of note is that most respondents were unaware of tourism policies that impacted their businesses and, like many tourism SMME, felt excluded from decision-making processes around tourism.

\section{CONCLUSION}

As national space economies - as well as tourism space economies - become more polarised the impacts of 'peripherality' become imprinted upon the development dynamics of remote and marginal spaces (Pezzi \& Urso, 2016, 2017; Todes \& Turok, 2018; Lang \& Görmar, 2019; Pezzi et al., 2019). Against this backdrop the subject of peripheral tourism is important for tourism scholarship. Arguably, often there are complex management and development challenges surrounding tourism in peripheral regions (Hohl \& Tisdell, 1995; Moscardo, 2005; Brouder, 2013; Pezzi, 2017a; Salvatore et al., 2018). The objective in this research was to expand international debates surrounding 'tourism in peripheries' and of peripheral tourism development applying a longitudinal approach to provide a chronicle of the evolution of tourism in one particular marginal tourism region of the global South. The case study of the King Sabata Dalindyebo Local Municipality represents a peripheral region of South Africa and is of special interest for incorporating much of the territory that was the former Transkei homeland. The analysis highlights the early emergence and changing evolution of tourism in the area which was radically impacted by apartheid and Transkei 'independence'. It is shown that the growth of different forms of tourism in this municipality exhibits marked historical and spatial variations between the municipality's inland and coastal areas. In addition, despite tourism being identified as 
one of key drivers for local development, the contemporary tourism economy of this peripheral region shows signs of serious decline. This local municipality - like most local governments in South Africa's distressed regions - lacks the essential institutional capacity in order to maximise its local assets for tourism development. As a consequence, support interventions will be required from higher levels of South African government for ensuring the revival and sustainability of this local tourism economy.

\section{Acknowledgements}

Thanks to South Africa's National Department of Tourism for funding this research, to Zinzi Sixaba and Thobeka Dlomo for research assistance and to Arno Booyzen for preparing the map.

\section{REFERENCES}

Ashley, C. \& Ntshona, Z. (2003). Transforming Roles but Not Reality?: Private Sector and Community Involvement in Tourism and Forestry Development on the Wild Coast, South Africa. Brighton: University of Sussex Institute of Development Studies, Sustainable Livelihoods in Southern Africa, Research Paper No. 6

Brouder, P. (2013). Tourism Development in Peripheral Areas: Processes of Local Innovation and Change in Northern Sweden. PhD thesis, Department of Tourism Studies and Geography, Mid-Sweden University, Ostersund.

Brown, F., Hall, D.D. \& Hall, D.R. eds (2000). Tourism in Peripheral Areas: Case Studies. Clevedon: Channel View.

Carlyle-Gall, C. (1937). Six Thousand Miles of Sunshine Travel Over the South African Railways. Johannesburg: South African Railways and Harbours.

Chaperon, S. \& Bramwell, B. (2013). Dependency and Agency in Peripheral Tourism Development. Annals of Tourism Research, 40, 132-154.

Christaller, W. (1964). Some Considerations of Tourism Location in Europe: The Peripheral Regions Underdeveloped Countries - Recreation Areas. Papers in Regional Science, 12 (1), 95-105.

Crush, J. \& Wellings, P. (1983). The Southern African Pleasure Periphery 1966-83. Journal of Modern African Studies, 21, 673-698.

de Witt, A. \& Ndzamela, E. (2018). KSD. Johannesburg: South African Cities Network.

Dinis, A. \& Krakover, S. (2016). Niche Tourism in Small Peripheral Towns: The Case of Jewish Heritage in Belmonte, Portugal. Tourism Development \& Planning, 13 (3), 310-332.

Dzinotyiweyi, G. (2009). Making Place Through Urban Restructuring: The Case of Mthatha. Masters Dissertation (City Planning and Urban Design), University of Cape Town, Cape Town.

East London Publicity Association (1935). East London Border and Transkeian Territories. East London Publicity Association and South African Railways and Harbours, available at National Library of Cape Town. A 1983-395.

Eastern Cape Socio-Economic Consultative Council (2017). King Sabata Dalindyebo Local Municipality SocioEconomic Review and Outlook, 2017. East London: Eastern Cape Socio-Economic Consultative Council

Grundlingh, A. (2006). Revisiting the 'Old' South Africa: Excursions into South Africa's Tourism History Under Apartheid, 1948-1990. South African Historical Journal, 56, 103-122.

Hall, C.M. (2013). Vanishing Peripheries: Does Tourism Consume Places? Tourism Recreation Research, 38 (1), $72-77$.

Harrison, K. (2008). Can Mthatha Turn the Corner? Delivery, 18, $24-27$.

Heer, B. (2007). Commodification and Cultural Tourism: An Inquiry in the Backpacker Resort Coffee Bay. Unpublished project report, University of Basel, Switzerland.

Hohl, A. \& Tisdell, C. (1995). Peripheral Tourism: Development and Management. Annals of Tourism Research, 22 (3), 517-534.

Hotel Board, South Africa (1972). Guide to the Hotels in South Africa: Official Publication of the Hotel Board, South Africa. Johannesburg: Chris Van Rensburg Publications.

Hotel Guide Association (1965). Guide to the Hotels of South Africa and Adjacent Territories. Johannesburg: The Hotel Guide Association.

Keller, C.P. (1987). Stages of Peripheral Tourism Development - Canada's Northwest Territories. Tourism Management, 8, 20-32

Kepe, T., Ntsebeza, L. \& Pithers, L. (2001). Agri-Tourism Spatial Development Initiatives in South Africa: Are They Enhancing Rural Livelihoods?. London: Overseas Development Institute, Natural Resource Perspectives No. 65 . 
King Sabata Dalindyebo Municipality (2016). King Sabata Dalindyebo Municipality: Final Draft IDP Review 2016/17. Mthatha: King Sabata Dalindyebo Municipality.

King Sabata Dalindyebo Municipality (2019). King Sabata Dalindyebo Municipality: IDP Review 2019/2020. Mthatha: King Sabata Dalindyebo Municipality.

Kyle Business Projects (2010). King Sabata Dalindyebo Local Municipality Responsible Tourism Sector Plan. Report prepared for King Sabata Dalindyebo Local Municipality by Kyle Business Projects, Port Elizabeth.

Lang, T. \& Görmar, F. eds. (2019). Regional and Local Development in Times of Polarisation: Re-Thinking Spatial Policies in Europe. Singapore: Palgrave Macmillan.

Mbontsi, N.S. (2008). An Evaluation of the Role of Local Economic Development in Promoting Infrastructural Development: A Case Study King Sabata Dalindyebo Local Municipality. MSocial Sciences (Development Studies) thesis, University of Fort Hare.

Mgxekwa, B.B., Scholtz, M. \& Saayman, M. (2019a). So You Want To Walk in the Footsteps of a Legend, But What Are You Willing to Pay?: The Case of the Nelson Mandela Heritage sites. Journal of New Generation Sciences, 16 (1), 79-100.

Mgxekwa, B.B., Scholtz, M. \& Saayman, M. (2019b). A Typology of Memorable Experiences at Nelson Mandela Heritage Sites. Journal of Heritage Tourism, 14 (4), 325-339.

Moscardo, G. (2005). Peripheral Tourism Development: Challenges, Issues and Success Factors. Tourism Recreation Research, 30 (1), 27-43.

Msi, A.Z. (2009). Enterprise Development Trends: A Case Study of Mthatha, King Sabata Dalindyebo Municipality. MBA thesis, University of KwaZulu-Natal, Durban.

Müller, D.K. \& Jansson, B. eds. (2007). Tourism in Peripheries: Perspectives from the Far North and South. Wallingford: CABI.

Mzamo, B. (2018). Assessing the Relationship Between Urban Blight and City Attractiveness: The Case of Mthatha CBD. Masters in Town and Regional Planning Dissertation, University of KwaZulu-Natal.

Nel, E. \& Rogerson, C.M. (2016). The Contested Trajectory of Applied Local Economic Development in South Africa. Local Economy, 31(1-2), 109-123.

Ngcukana, L. (2018). Wild Coast Special Economic Zone Could Create Thousands of Jobs. City Press, 9 September.

Ngwira, C.M. (2011). Human Trafficking in Eastern Cape Province, South Africa. MSc degree (Geography \& Environmental Science), University of Fort Hare, Alice.

O.R. Tambo District Municipality (2017). Integrated Development Plan, 2017-2022. Mthatha: O.R. Tambo District Municipality.

Pezzi, M.G. (2017a). From Peripheral Hamlet to Craft Beer Capital: Apecchio and the 'Álogastronomia'. Italian Journal of Planning Practice, 7 (1), 154-185.

Pezzi, M.G. (2017b). When History Repeats: Heritage Regeneration and Emergent Authenticity in the Marche's Peripheral Areas. Almatourism - Journal of Tourism, Culture and Territorial Development, 8 (7), 1-20.

Pezzi, M.G. \& Urso, G. (2016). Peripheral Areas: Conceptualizations and Policies. Italian Journal of Planning Practice, 6 (1), 1-19.

Pezzi, M.G. \& Urso, G. (2017). Coping With Peripherality: Local Resilience Between Policies and Practices. Italian Journal of Planning Practice, 7 (1), 1-23.

Pezzi, M.G., Faggian, \& Reid, N. (2019). Local Entrepreneurship and Tourism Development in Peripheral Areas Between Policies and Practices. Regional Science Policy \& Practice, 11 (3), 445-449.

Pike, A., Rodriguez-Pose, A., Tomaney, J. (2006). Local and Regional Development. London: Routledge.

Pike, A., Rodriguez-Pose, A., Tomaney, J. eds. (2015). Local and Regional Development, 4 vols. London: Routledge. Rand Daily Mail (Johannesburg Newspaper), 24 July 1980.

Republic of Transkei (1981). Transkei Official Tourist and Commercial Guide. Durban: Advertising Sales Promotion on Behalf of the Department of Planning and Commerce, Transkei.

Rogerson, C.M. (2011). Youth Tourism in Africa: Evidence from South Africa. Tourism Analysis, 16, 105-120.

Rogerson, C.M. (2014a). Reframing Place-based Economic Development in South Africa: The Example of Local Economic Development. Bulletin of Geography: Socio-Economic Series, 24, 203-218.

Rogerson, C.M. (2014b). Rethinking Slum Tourism: Tourism in South Africa's Rural Slumlands. Bulletin of Geography: Socio-Economic Series, 26, 19-34.

Rogerson, C.M. (2015). Tourism and Regional Development: The Case of South Africa's 'Distressed Areas'. Development Southern Africa, 32, 277-291.

Rogerson, C.M. (2019). Business Tourism Under Apartheid: The Historical Development of South Africa's Conference Industry. Urbani izziv, 30 (Supplement), 82-95

Rogerson C.M. \& Rogerson, J.M. (2018). The Evolution of Hotels in Johannesburg 1890-1948: A Case of Historical Urban Tourism. GeoJournal of Tourism and Geosites, 23 (3), 732-738. 
Rogerson, C.M. \& Rogerson, J.M. (2019a). Tourism, Local Economic Development and Inclusion: Evidence from Overstrand Local Municipality, South Africa. GeoJournal of Tourism and Geosites, 25 (2), 293-308.

Rogerson, C.M. \& Rogerson, J.M. (2019b). Historical Urban Tourism: Developmental Challenges in Johannesburg 1920-1950. Urbani izziv, 30 (Supplement), 112-128.

Rogerson, J.M. (2017). 'Kicking Sand in the Face of Apartheid': Segregated Beaches in South Africa. Bulletin of Geography: Socio-Economic Series, 35, 93-109.

Rogerson, J.M. (2018). The Geography of Tourist Bednights in South Africa. GeoJournal of Tourism and Geosites, 23 (3), 835-847.

Salvatore, R. Chiodo, E. \& Fantini, A. (2018). Tourism Transition in Peripheral Rural Areas: Theories, Issues and Strategies. Annals of Tourism Research, 68, 41-51.

Sitinga, S.B. \& Ogra, A. (2014). Place-making in Tourism-led Local Economic Development (LED): A Case Study of Coffee Bay, Wild Coast, Eastern Cape Province, South Africa. In Proceedings Planning Africa 2014, International Convention Centre, Durban, 19-22 October.

Sixaba, Z. \& Rogerson, C.M. (2019). Black Economic Empowerment and South African Tourism: The Early Pioneers. African Journal of Hospitality, Tourism and Leisure, 8 (4), 1-10.

Siyongwana, P. Q. (2005). Transformation of Residential Planning in Umtata During the Post-apartheid Transition Era. GeoJournal, 64, 199-213.

Siyongwana, P. Q. (2009). The Impact of Political Transformation on Employment in the Transkei Bureaucracy and Civil Service in Umtata, South Africa, Since 1994. GeoJournal, 74, 293-310.

South African Railways and Harbours (1936). Illustrated Guide to Hotels and Boarding Houses, 1936. Pretoria: Government Printer.

South African Railways Tourist Office (1949). South African Native Studies. Johannesburg: South African Railways Tourist Office.

Streek, B. \& Wicksteed, R. (1981). Render Unto Kaiser: A Transkei Dossier. Johannesburg: Ravan Press.

Todes, A. \& Turok, I. (2018). Spatial Inequalities and Policies in South Africa: Place-based or People-centred?. Progress in Planning, 123, 1-31.

Tsheleza, V., Ndhleve, S., Kabiti, H.M., Musampa, C.M. \& Nakin, M.D.V. (2019). Vulnerability of Growing Cities to Solid Waste-related Environmental Hazards: The Case of Mthatha, South Africa. Jamba: Journal of Disaster Risk Studies, 11 (1): 632. doi: 10.4102/jamba.v11i1.632

The Union Publishing Agency (1921). Illustrated South African Hotel Guide for Travellers and Tourists 192021. Cape Town: Cape Times.

Visser, G. (2004). The Developmental Impact of Backpacker Tourism in South Africa. GeoJournal, 60, $283-299$.

Wanhill, S. (1997). Peripheral Area Tourism: A European Perspective. Progress in Tourism and Hospitality Research, 3, 47-70.

Wildman, K. (2005). The Beach: The Making \& Remaking of Coffee-Bay (1945-2005). MPhil dissertation in Public Culture, Centre for African Studies, University of Cape Town, Cape Town.

Submitted:

02.07.2019
Revised:

15.10.2019
Accepted and published online 16.10.2019 